\title{
Determination of the Expression Rate of Ethyl Acetate Hydrolysis Reaction Depending on the Temperature
}

\author{
Alime ÇITAK ${ }^{1 *}$ \\ Arif KIVRAK ${ }^{2}$
}

\begin{abstract}
In this scientific study, the hydrolysis reaction was carried out in a batch reactor to test which order of the reaction is, the rate constant at different temperatures and also, activation energy, and frequency factor. For this purpose, this hydrolysis reaction was experimentally performed the time-dependent $\mathrm{NaOH}$ consumption in a batch reactor in the different temperature range $(283 \mathrm{~K}-313$ $\mathrm{K})$. The results show that hydrolysis of the ethyl acetate is a forward one-way second order reaction. The analysis of the experimental data showed that the activation energy is $29.775 \mathrm{~kJ} \mathrm{~mol}^{-1}$ and frequency factor 27038.
\end{abstract}

Keywords: Activation energy, arrhenius equation, ethyl acetate, hydrolysis reaction, batch reactor

\section{Sıcaklığa Bağlı Olarak Etil Asetat Hidroliz Tepkimesi Hız İfadesinin Belirlenmesi}

ÖZET: Bu bilimsel çalışmada, etilasetatın hidroliz reaksiyonu tepkime mertebesinin ne olduğunu, farklı sıcaklıklarda hız sabitini ve aynı zamanda aktivasyon enerjisini ve frekans faktörünü kesikli bir reaktörde test etmek için gerçekleştirildi. Bu amaçla, bu hidroliz reaksiyonu, kesikli bir reaktörde farklı sıcaklık aralığında (283-313 K) zamana bağlı NaOH tüketimi ile deneysel olarak gerçekleştirildi. Sonuçlar etil asetatın hidrolizinin tersinmez ikinci dereceden bir reaksiyon olduğunu göstermektedir. Deneysel verilerin analizi, aktivasyon enerjisinin $29.775 \mathrm{~kJ} \mathrm{~mol}^{-1}$ ve frekans faktörünün 27038 olduğunu gösterdi.

Anahtar kelimeler: Aktivasyon enerjisi, arhenius eşitliği, etilasetat, hidroliz tepkimesi, kesikli reaktör

\footnotetext{
${ }^{1}$ Alime ÇITAK (Orcid ID: 0000-0002-3143-6646), Department of Chemical Engineering, Eskisehir Osmangazi University, Eskisehir, Turkey

${ }^{2}$ Arif KIVRAK (Orcid ID: 0000-0003-4770-2686), Department of Chemistry, Van Yuzuncu Yil University, 65080 Van, Turkey

*Sorumlu yazar/Corresponding Author: Alime ÇITAK, citakalime@gmail.com
} 


\section{INTRODUCTION}

Zia-ul-Haq et al define the saponification reaction is the hydrolysis of an ester with basic conditions to produce an alcohol and the sodium salt of carboxylic acid. This term is mostly used in order to identify reaction which occurs in the alkaline condition with a fat to convert into soap. So, the hydrolysis of ethyl acetate to produce the sodium salt of acetic acid ( $\mathrm{NaOAc}$ ), and ethyl alcohol with caustic soda is called as saponification reaction, but even though the final

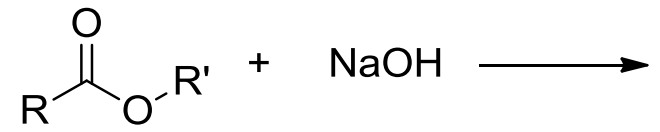

Figure 1. The hydrolysis reaction of acetate

In another study, It has been found that hydrolysis of ethyl acetate with caustic soda has a reaction order 1.3118 and can not be expressed satisfactorily as a 2nd order reaction specially when same concentrations of both reactants are reacted (Mukhtar et al., 2017).

Kim and Baird mentioned that in the saponification of ethyl acetate, the value of electrical conductance can be used to measure the progress of the reaction when the reactants in the reactor are intense electrolytes. Also, they explained that the rate of hydrolysis of ethyl acetate with caustic soda was measured close the cloud point of the liquid mixture (Kim and Baird, 2004).

Mukhtar et al. determined the parameters of Arrhenius equation which are frequency factor and activation energy. They found that activation energy as $43.094 \mathrm{~kJ}^{\text {mole }}{ }^{-1}$ for ethyl acetate saponification. They were experimentally performed in a Batch Reactor for the parameters of the saponification reaction rate and used the Electrical Conductivity (Mukhtar et al., 2015)

DAS et al. used an conductometric measurement which is a non-traditional technique. They observed the kinetic behavior of product was not soap in the (Zia-ul-Haq et al., 2014).

The most used reactions in engineering laboratories is hydrolysis reactions and the theory of reactors used can be explained in a simple way. The effect is the second-order reaction of the hydrolysis of acetate (Kapoor, 2004). As a result of the reaction, such as, sodium salt of acetic acid ( $\mathrm{NaOAc}$ ), and alcohol are generated as shown below (Figure 1), making the one-way reaction (Kuheli et al., 2011; Paul and Daniel, 2014).

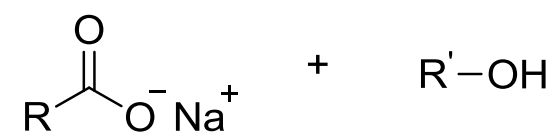

the reaction of ethyl acetate with caustic soda. Additionally, they studied the use of conductivity meter for a fast kinetic measurement. They determined rate constants of the hydrolysis reaction at the various temperatures. Also, they evaluated some parameters that kinetic and thermodynamic (Das et al., 2011).

Some authors mentioned that the reaction products, sodium acetate and ethanol, have not only an commercial importance for cleaning purposes. They explained that they have a wide industrial application areas. For example, in pharmaceutical and electroplating industries, paint in the area (Malik et al., 2015; Ullah and Ahmad, 2015).

Fat acids are an undesirable concept in the oil industry. It is an important place in the quality of oils. The lower the oil level in an oil, the better the oil quality. The hydrolysis reactions can be used to remove the free fatty acids in the industrial oil. The soap residue obtained in this stage is evaluated in the soap industry (Zia-ulHaq et al., 2014).

In small-scale pilot plants, disconnected reactors that is, batch reactor can be used to 
obtain preliminary information. Intermittent reactors are also the reason for preference for new product production in small quantities developed in higher purity yield. These reactors include excellent mixer systems and some internal cleaning units (Levenspiel, 1999).

The hypothesis of this study is to show the suitability of the hydrolysis reaction to the second-order reaction model in the batch reactor. For this reason in this study; it was determined the reaction order, the forward rate constant, activation energy, and frequency factor for the saponification reaction of ethylacetate by $\mathrm{NaOH}$ by means of a batch reactor in the temperature range $(283 \mathrm{~K}-313 \mathrm{~K})$.

\section{MATERIAL AND METHOD}

\section{Chemicals}

Sodium Hydroxide (NaOH) (Merck), Ethyl Acetate $\left(\mathrm{CH}_{3} \mathrm{COOC}_{2} \mathrm{H}_{5}\right)$ (Merck)

\section{The Experimental Setup and Method}

The hydrolysis reaction was attempted in a batch apparatus. The reactor used is a glass cylinder with a stainless steel base in which allows the reactants in the reactor to react at the desired rate and the desired temperature. By means of the agitator motor it is ensured that the concentration of liquid in the reactor is the same at every point.

For batch reactor experimens, the equal volume of reactants was used. Ethyl acetate was added severally into the $500 \mathrm{ml}$ reactor which contains caustic soda and then, mixed at constant stirring speed. Before starting of the experiment in the study, the solution temperature in the reactor should be close to the same temperature as much as possible. $10 \mathrm{ml}$ of each of the samples were withdrawn into a $10 \mathrm{ml}$ conical flask containing $0.1 \mathrm{~N} \mathrm{HCl}$, and titrated against $0.1 \mathrm{~N} \mathrm{NaOH}$ solution using phenolphthalein as indicator. Concentrations of both reactants in the reactor were determined. At specific time interval, the procedure was continued until limiting reactant (ethyl acetate) depletion. The experiments were repeated with agitation at different temperatures.

\section{Reaction Kinetics}

Basic hydrolysis of an ester (ethyl acetate) with a caustic soda, also called saponification, is a nonreversible second-order reaction (Tsujikawa and Inoue, 1966; Kuheli et al., 2011; Ikhazuangbe et al., 2015).

The reaction mechanism for the saponification reaction is given as follows $\mathrm{NaOH}+\mathrm{CH}_{3} \mathrm{COOC}_{2} \mathrm{H}_{5} \rightarrow \mathrm{CH}_{3} \mathrm{COONa}+$ $\mathrm{C}_{2} \mathrm{H}_{5} \mathrm{OH}$

As before, the rate at which $\mathrm{A}$ and $\mathrm{B}$ decrease can be expressed using the differential rate equation:

$$
-r_{A}=-\frac{d C_{A}}{d t}=-\frac{d C_{B}}{d t}=k C_{A} C_{B}
$$

when integrated, after rearrangement, the final result is

$$
\ln \left(\frac{C_{A}}{C_{B}}\right)=\ln \left(\frac{C_{A 0}}{C_{B 0}}\right)+\left(C_{A 0}-C_{B 0}\right) k \cdot t
$$

where subscripts A, B refer to alkali (sodium hydroxide), ester (ethyl acetate), respectively, $\mathrm{k}$ is forward reaction rate constant.

According to reaction kinetics; $\ln \left(\mathrm{C}_{\mathrm{A}} / \mathrm{C}_{\mathrm{B}}\right)$ graphs are plotted against the time, $t$ from the experimental data. By using the obtained linear equation, the reaction rate constant is found for the working temperature. In this plot, $\ln \left(\mathrm{C}_{\mathrm{Ao}} /\right.$ $\left.\mathrm{C}_{\mathrm{Bo}}\right)$ slip value and $\mathrm{k}\left(\mathrm{C}_{\mathrm{Ao}}-\mathrm{C}_{\mathrm{Bo}}\right)$ slope are given ( Levenspiel, 1999).

\section{Determination of the Activation Energy}

The temperature dependent term $(\mathrm{k}$; the rate constant of the reaction) is measured by using the Arrhenius Equation (Ahmad et al., 2013).

Further experiments were held at the desired reaction temperatures to determine the rate constant of the reaction at different temperatures. On the other hand, the activation energy $\left(E_{a}\right)$, which is the kinetic variable of the reaction, is found in the Arrhenius equation. Logarimetric 
expression of the Arrhenius equation; So, it can be written as

$$
\ln k=\ln A-\frac{E_{a}}{R T}
$$

where $E_{a}$, activation energy; $A$, frequency factor. By plotting the graph between $1 / \mathrm{T}$ against (-lnk); the slope of straight-line obtained from the graph will give the value of $E_{a} / R$ and $A$, frequency factor will be obtained from the cut point, respectively (Figure 6).

\section{RESULTS AND DISCUSSION}

The hydrolysis reaction of ethyl acetate is an one-way second order (Wijayarathne and Wasalathilake, 2014), 1st order according to both reactants. This reaction was carried out in non-catalytic and a liquid system. This reaction was a non-heterogeneous phase (liquid/liquid) reaction and slightly exothermic. The rate of a chemical reaction is usually depend upon the temperature and composition ( Das et al., 2011).

\section{Reaction Kinetics}

The time-dependent $\mathrm{NaOH}$ consumption at the range of temperatures $(283 \mathrm{~K}-313 \mathrm{~K})$ in the batch reactor was obtained from the experimental studies. Some graphical results are shown in Figure (2-5), where the concentration change was plotted as $\ln \left(\mathrm{C}_{\mathrm{A}} / \mathrm{C}_{\mathrm{B}}\right)$ against the reaction time, $\mathrm{t}$ for the hydrolysis reaction at different solution temperatures. A linear line was obtained from the graphs. It was proven to be an irreversible second order reaction occurs as a result of experimental data. The slopes of straight-line will give the values of $\left(\mathrm{C}_{\mathrm{A} 0}-\right.$ $\left.\mathrm{C}_{\mathrm{B} 0}\right) \mathrm{k}$ in Figure (2-5) when we draw the graph between $\ln \left(\mathrm{C}_{\mathrm{A}} / \mathrm{C}_{\mathrm{B}}\right)$ on the ordinate and $\mathrm{t}$ ( time) on the axis,

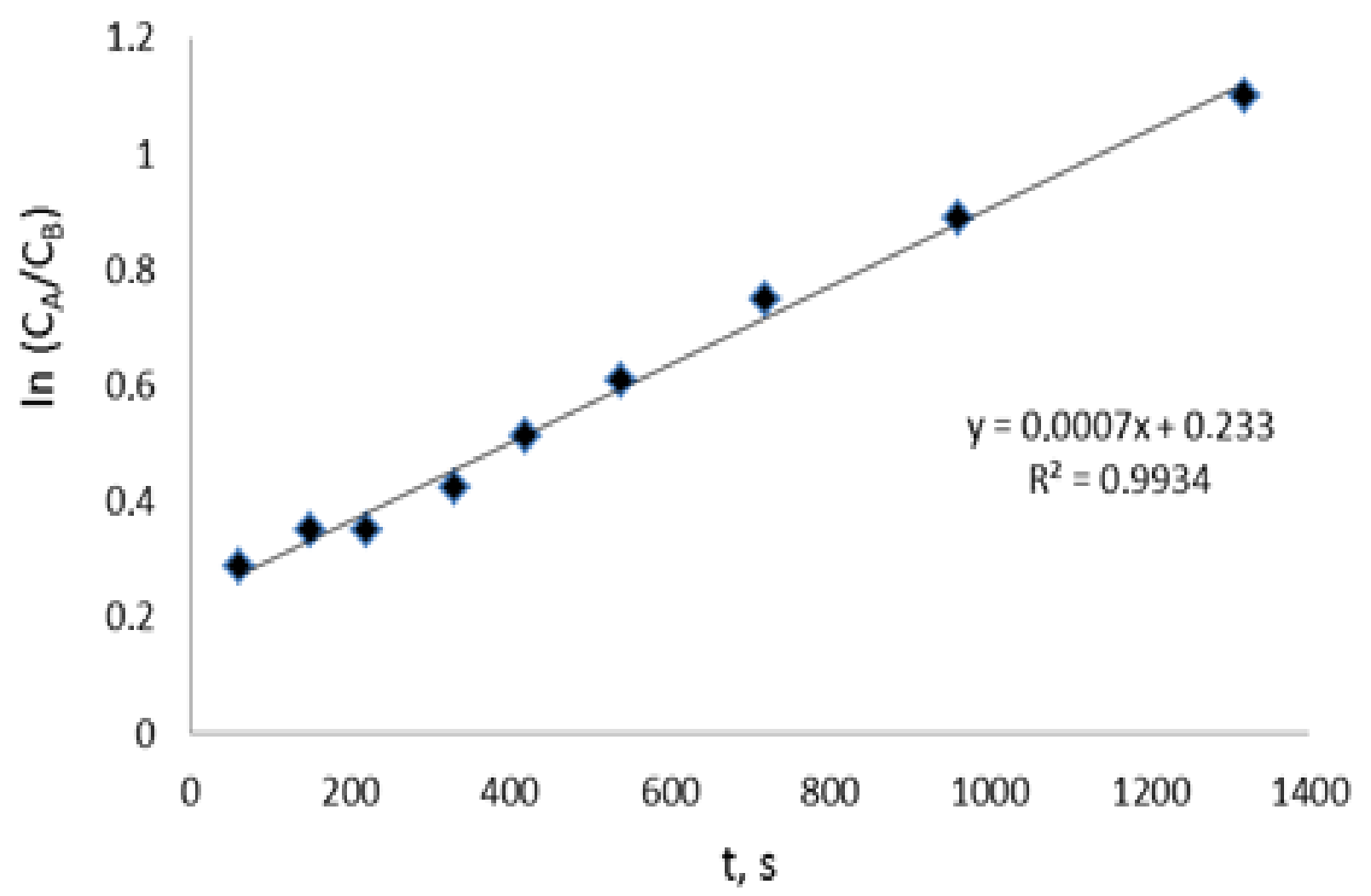

Figure 2. $\ln \left(\mathrm{C}_{\mathrm{A}} / \mathrm{C}_{\mathrm{B}}\right)$ versus time for the hydrolysis reaction at a constant reactor temperature $\left(\mathrm{T}=283 \mathrm{~K}, \mathrm{C}_{\mathrm{Ao}}=\right.$ $\left.0.05146 \mathrm{M}, \mathrm{C}_{\mathrm{Bo}}=0.04115 \mathrm{M}\right)$ 


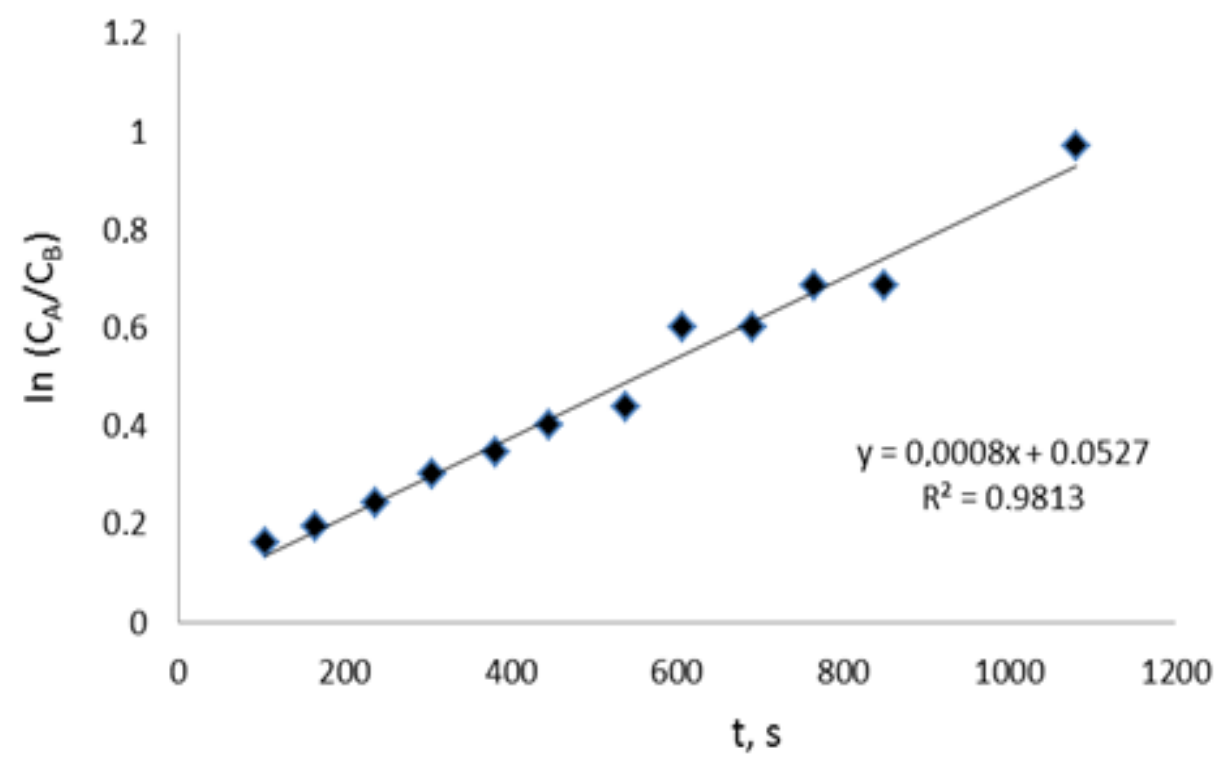

Figure 3. $\ln \left(C_{A} / C_{B}\right)$ versus time for the hydrolysis reaction at a constant reactor temperature $\left(T=293 \mathrm{~K}, \mathrm{C}_{\mathrm{A}_{0}}=\right.$ $\left.0.05146 \mathrm{M}, \mathrm{C}_{\mathrm{Bo}}=0.04115 \mathrm{M}\right)$

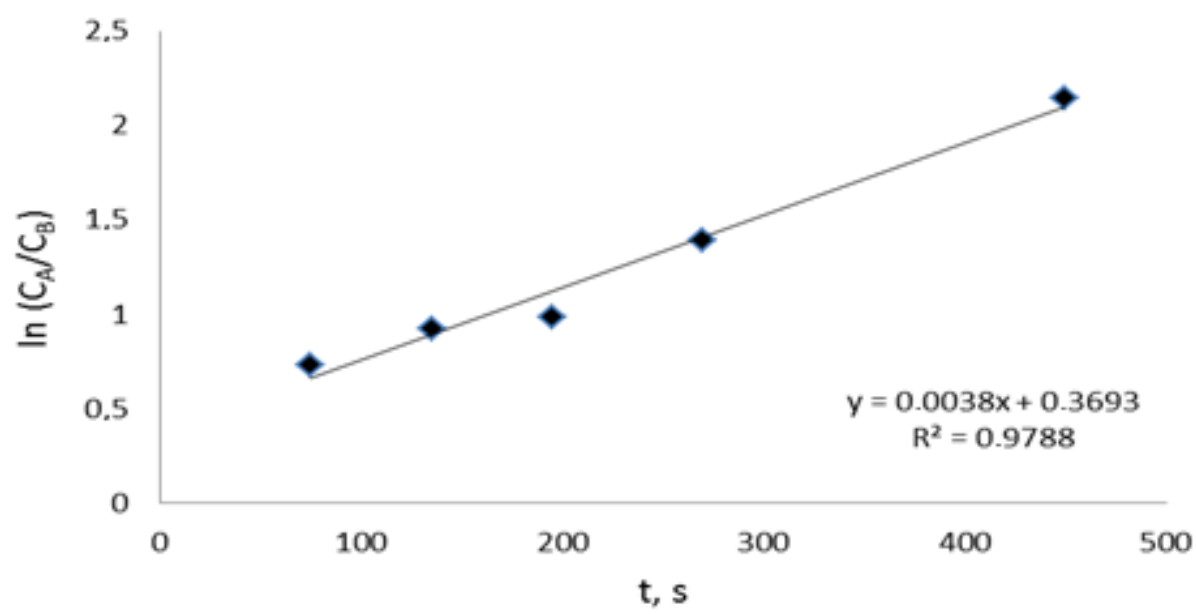

Figure 4. $\ln \left(\mathrm{C}_{\mathrm{A}} / \mathrm{C}_{\mathrm{B}}\right)$ versus time for the hydrolysis reaction at a constant reactor temperature $\left(\mathrm{T}=303 \mathrm{~K}, \mathrm{C}_{\mathrm{Ao}}=\right.$ $\left.0.05146 \mathrm{M}, \mathrm{C}_{\mathrm{Bo}}=0.04115 \mathrm{M}\right)$

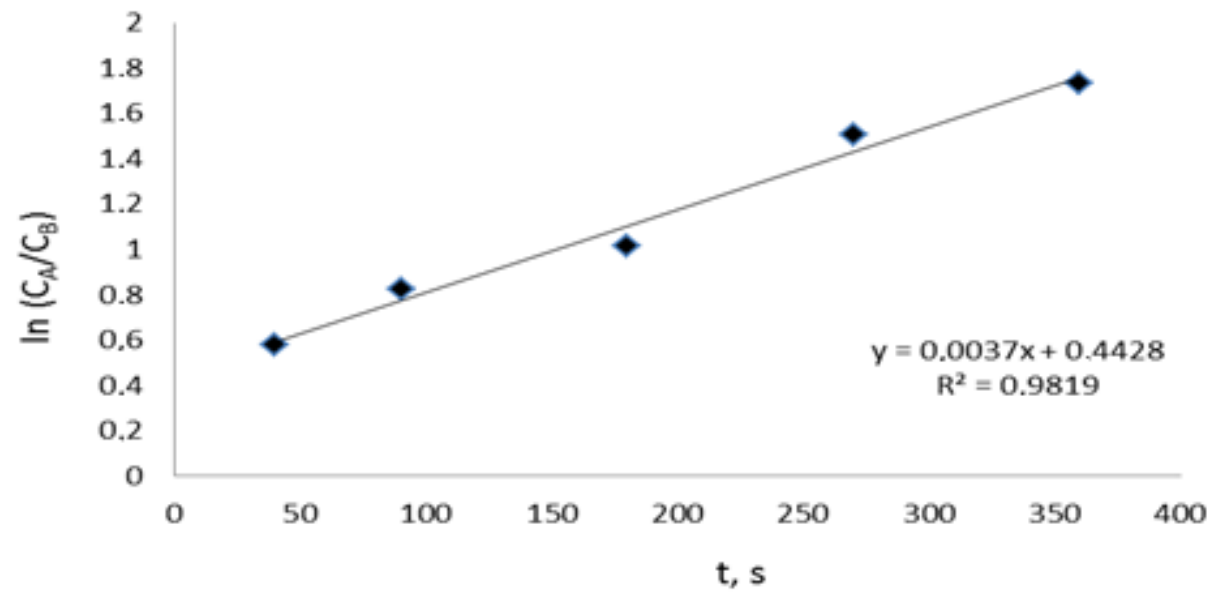

Figure 5. $\ln \left(C_{A} / C_{B}\right)$ versus time for the hydrolysis reaction at a constant reactor temperature $(T=313 \mathrm{~K})$ 


\section{Effect of Temperature on the Reaction}

The values of rate constant $(\mathrm{k})$ determined are given below in Table 1 at the range of temperatures $(283 \mathrm{~K}-313 \mathrm{~K})$. Where, $\mathrm{k}$ is the forward rate constant and calculated by means of the Arrhenius equation for four different temperatures. Arrhenius equation to express the temperature dependence of the reaction rate constant plays an active role in studies of chemical kinetics. When we draw the graph between $1 / \mathrm{T}$ on the axis and -lnk on the ordinate, the slope of straight-line obtained from the graph will give the value of $E_{a} / R$ ( Figure 6).

Table 1. Forward rate constants of the hydrolysis reaction at different temperatures

\begin{tabular}{lllll}
\hline Temperature $(\mathrm{K}):$ & 283 & 293 & 303 & 313 \\
$\mathrm{k}$, forward rate constant $\left(\mathrm{L} \mathrm{mol}^{-1} \mathrm{~s}^{-1}\right):$ & 0.0776 & 0.1515 & 0.237 & 0.2566 \\
\hline
\end{tabular}

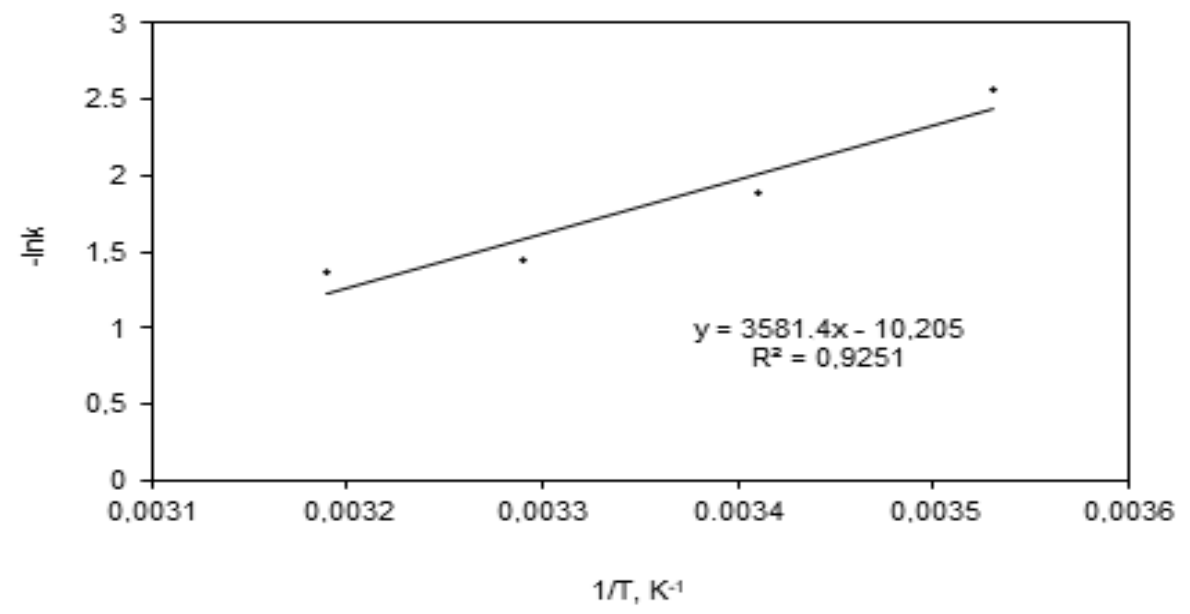

Figure 6. Arrhenius'law of the second-order rate coefficient for the ethyl acetate hydrolysis reaction

\section{CONCLUSION}

The experimental results shows that the hydrolysis of ethyl acetate are the second order reaction. The hypothesis supposed was experimentally confirmed. As a result of the reaction, sodium acetate and ethanol were obtained. Reaction order can only be calculated in experiment and can only be predicted if the reaction mechanism. As seen in Figure (2-5), a linear line was obtained from the graphs plotted to test for a homogeneous second order. This proved, experimentally that the hydrolysis reaction of ethyl acetate is an one-way second order.

The hydrolysis reaction is a reaction which depends on the temperature and the reaction rate increases as the temperature increases. This situation can also be seen from the data (Table 1) due to the decrease of the reaction time. The Activation Energy, $E_{a}$, and frequency factor, A, were calculated by taking advantage of the Arrhenius equation, which gives rise to a change in reaction rate constant with temperature. The results show that the value of activation energy that ensures to make the hydrolysis reaction progressed is $29.775 \mathrm{~kJ} \mathrm{~mol}^{-1}$ and frequency factor is 27038 .

The various studies on the forward rate constants at the different temperatures and activation energy of the hydrolysis reaction ethyl acetate and sodium hydroxyde have been conducted by several investigators. So, there are many data at various intervals (Schneider et al., 
2005; Das et al., 2011). Das et al. reported that the rate constant is $0.16 \mathrm{~L} \mathrm{~mol}^{-1} \mathrm{~s}^{-1}$ at $30{ }^{\circ} \mathrm{C}$ and the amount of the activation energy is 41.4 $\mathrm{kJmol}^{-1}$ in their work. In the present work, it was found that the rate constant is $0.237 \mathrm{Lmol}^{-1} \mathrm{~s}^{-1}$ at $30{ }^{\circ} \mathrm{C}$ and the amount of activation energy is $29.775 \mathrm{kJmol}^{-1}$, which was about $28 \%$ lower than the value submitted by Das et al. ( Das et al., 2011). So, it was possible to obtain the rate constant of a familiar method at the studied temperatures in a much simpler way.

Consequently, in the present study, the rate expression of the hydrolysis reaction of ethylacetate with sodium hydroxide in the batch reactor can be given by

$$
-\mathrm{r}=\exp \left(10.2-\frac{3581}{T}\right) C_{\mathrm{NaOH}} C_{\mathrm{CH} 3 \mathrm{COOC} 2 \mathrm{H} 5} ; \mathrm{mol} \mathrm{L}^{-1} \mathrm{~S}^{-1}
$$

\section{REFERENCES}

Ahmad A, Ahmad MI, Younas M, Khan H, Shah $\mathrm{MH}, 2013$. A comparative study of alkaline hydrolysis of ethyl acetate using design of experiments. Iranian Journal of Chemistry and Chemical Engineering, 32: 33-47.

Das K, Sahoo P, Sai Baba M, Muralı N, Swamınathan P, 2011. Kinetic studies on saponification of ethyl acetate using an innovative conductivity-monitoring instrument with a pulsating sensor. International Journal of Chemical Kinetics, 43: 648-656.

Ikhazuangbe PMO, Oni AB, 2015. Reaction rate and rate constant of the hydrolysis of ethyl acetate with sodium hydroxide. American Journal of Scientific and Industrial Research, 6: 1-4.

Kapoor, KL, 2004. A Textbook of Physical Chemistry; McMillan: New Delhi, Vol. 5, 116 p, India.

Kim YW, Baird JK, 2004. Reaction kinetics and critical phenomena: saponification of ethyl acetate at the consolute point of 2butoxyethanol + water. International Journal of Thermophysics, 25: 1025-1036.

Levenspiel O, 1999. Chemical Reaction Engineering. John Wiley, Third Edition, NY. 668 p, New York.
Malik SR, Awan BA, Shafiq U, Mukhtar A, 2015. Investigation of the Agitation Effect on the Conversion of Saponification Reaction in a Batch Reactor at STP Conditions. International Journal of Applied Sciences and Engineering Research, 4: 461-466.

Mukhtar A, Shafiq U, Khan AF, Qadir HA, Qizilbash M, 2015. Estimation of parameters of arrhenius equation for ethyl acetate saponification reaction. Research Journal of Chemical Sciences, 5: 46-50.

Mukhtar A, Shafiq U, Qazi MO, Qadir HA, Qizilbash M, Awan BA, 2017. Kinetics of alkaline hydrolysis of ethyl acetate by conductometric measurement approach over temperature ranges (298.15-343.15 K). Austin Chemical Engineering, 4: 1-11.

Paul OC, Daniel EC, 2014. Optimization of A Soap Production Mix Using Response Surface Modeling: A Case Of Niger Bar Soap Manufacturing Industry Onitsha, Anambra State, NigeriaIwenofu Chinwe Onyedika, Sinebe Jude Ebieladoh, International Journal of Scientific \& Technology Research, 3: 346352.

Schneider, MA, Stoessel F, 2005. Determination of the kinetic parameters of fast exothermal reactions using a novel microreactor-based calorimeter. Chemical Engineering Journal, 115: 73-83. 